\title{
PRINSIP KERJA SAMA DALAM BAHASA TRANSAKSI JUAL BELI ONLINE DI TOKOPEDIA.COM
}

\author{
Larasati Nourmalita Devi \\ Universitas Sebelas Maret \\ larasatinourmalita@gmail.com \\ Muh. Qomaruddin \\ Universitas Sebelas Maret \\ uddien64@yahoo.com
}

\begin{abstract}
This study belongs to a qualitative research. This research investigates the reasons of cooperative principle violation and obedience of language transaction in online shopping. The research was done by collecting data from Tokopedia.com. online shop. The data in this research are conversations which consist of speeches reflecting cooperative principle in transaction language of online shopping in Tokopedia.com along with the contexts. The source of data is Tokopedia.com online shop from January to March 2016. Data were analyzed using contextual heuristic method. The results show that there are four types of the cooperative principle violation and obedience: maxim of quantity, maxim of quality, maxim of relation, and maxim of manner with different motifs for each maxim.
\end{abstract}

Keywords: cooperative principle, transaction, online shopping

\begin{abstract}
Abstrak
Penelitian ini berbentuk kualitatif. Permasalahan dalam penelitian ini adalahalasan terjadinya pelanggaran dan pematuhan pinsip kerja sama dalam bahasa transaksi jual beli online di Tokopedia.com.Data dalam penelitian ini adalah percakapan yang didalamnya terdapat kalimat tuturan-tuturan yang mencerminkan penerapan prinsip kerja sama dalam bahasa transaksi jual beli online di Tokopedia.com beserta konteksnya. Sumber data pada penelitian ini adalah toko online Tokopedia.com pada bulan Januari - Maret 2016. Analisis menggunakan metode heuristik kontekstual. Dari hasil analisis dapat disimpulkan bahwa alasan terjadinya pelanggaran dan pematuhan prinsip kerja sama dalam bahasa transaksi jual beli online di Tokopedia.com ditemukan empat jenis pematuhan dan pelanggaran prinsip kerja sama yaitu, maksim kuantitas, maksim kualitas, maksim relevansi dan maksim cara dengan alasan masing-masing maksim berdasarkan motif-motif tertentu.
\end{abstract}

Kata Kunci: Prinsip kerja sama, transaksi,jual beli online 


\section{PENGANTAR}

Bahasa memegang peranan penting dalam masyarakat. Bahasa ditinjau dari segi fungsinya, memiliki fungsi beraneka ragam. Salah satu diantaranya yang paling menonjol adalah sebagai alat komunikasi. Hal tersebut berarti segala hal yang berkaitan dengan komunikasi atau interaksi akan lumpuh tanpa adanya bahasa. Penggunaan bahasa oleh suatu masyarakat dalam berinteraksi dapat dilakukan secara lisan maupun tulisan. Interaksi secara tertulis merupakan komunikasi dengan media tulisan, seperti SMS (Short Message Service), surat menyurat, dan lain sebagainya, sedangkan interaksi secara lisan dapat berupa pidato, dialog, atau percakapan antara dua orang atau lebih, seperti percakapan ditelepon, percakapan penjual dan pembeli di pasar, dan lain sebagainya.

Suatu komunikasi dapat berlangsung dengan baik dan mudah dipahami ketika penutur dan lawan tutur memiliki pengetahuan yang hampir sama atau sama. Selain itu, prinsip kerjasama antara penutur dan lawan tutur harus dilakukan dengan baik agar komunikasi berjalan lancar. Meskipun penyampaian tuturan disampaikan dengan pemilihan kata atau diksi yang berbeda, hal ini mudah dipahami oleh kedua peserta tutur jika keduanya memiliki pengetahuan yang hampir sama atau sama dan menjalankan prinsip kerja sama dalam percakapan.

H.P. Grice berpendapat tentang prinsip kerja sama sebagai berikut:
Suatu percakapan biasanya membutuhkan kerja sama antara penutur dan lawan tutur untuk mencapai suatu tujuan yang diinginkan. Prinsip yang mengatur kerja sama antara penutur dan mitra tutur dalam suatu percakapan dinamakan prinsip kerja sama (cooperative principle). Prinsip kerja sama Grice dirumuskan sebagai berikut "Make your conversational coontibution such as required, at the stage at which it accurs, by the accepted purpose or direction of the talk exchange in which you are engaged!" (Buatlah sumbangan informasi Anda seinformatif yang dibutuhkan pada saat berbicara, berdasarkan tujuan percakapan yang disepakati atau arah percakapan yang sedang diikuti) (Grice, 1975:45).

Komunikasi merupakan kegiatan sosial yang dapat terjadi dimana saja. Dalam kehidupan sehari-hari, interaksi itu dapat bermacam-macam bentuknya, misalnya bekerja, bermain, belajar, hingga komunikasi di pasar antara penjual dan pembeli. Adanya tawar menawar sebagai bentuk interaksi tentu melibatkan bahasa. Dengan demikian, tawar menawar termasuk salah satu peristiwa tutur (speech event). Menurut Suharsono faktor pemakaian bahasa adalah "Sebagai salah satu peristiwa tutur, wujud pemakaian bahasa dipengaruhi oleh berbagai faktor, seperti situasi dan peristiwa, peserta tutur, tujuan berbicara, norma-norma 
interaksi dan sebagainya" (Suharsono, 2003:1)

Tujuan interaksi antara penjual dan pembeli yang melibatkan peristiwa tutur atau konteks tersebut, saat ini tidak hanya ditemukan di pasar tradisional atau supermarket saja. Seiring perkembangan teknologi, transaksi jual beli saat ini dapat ditemukan di beberapa media online, baik melalui aplikasi sosial media maupun aplikasi jual beli online. Toko online merupakan salah satu tempat terjadinya aktifitas perdagangan atau jual beli barang yang terhubung ke dalam suatu jaringan dalam hal ini adalah internet. Aktifitas ini biasa juga disebut dengan belanja online.

Sama seperti transaksi di toko ataupun pasar biasa, di toko online proses transaksi yang dilakukan tidak jauh berbeda. Jika di toko atau pasar biasa dilayani oleh manusia, toko online dilayani oleh mesin internet. Pada saat proses jual beli berlangsung, banyak ditemukan penerapan prinsip kerja sama yang dimunculkan oleh penjual ataupun pembeli. Beberapa media jual beli online ternama di Indonesia adalah tokobagus, lazada, salestrore dan yang terakhir Tokopedia.com. Salah satu media jual beli online yang ramai dari sederet toko jual beli online tersebut adalah Tokopedia.com. Penelitian ini membahas mengenai alasan terjadinya pematuhan dan pelanggaran prinsip kerja sama dalam bahasa transaksi jual beli pada di Tokopedia.com.

\section{TEORI DAN METODE PENELITIAN}

Bentuk penelitian yang digunakan pada penelitian ini adalah kualitatif karena penelitian ini didasarkan pada masalah yang diajukan dalam penelitian ini, yaitu tentang bentuk prinsip kerja sama dalam bahasa transaksi jual beli online di Tokopedia.com. Hal ini didasarkan oleh pendapat Sudaryanto yang menyatakan bahwa penelitian ini menggunakan data penelitian yang tidak berupa angka-angka, tetapi berupa kata atau frasa (Sudaryanto, 1993:62).

Data yang digunakan dalam penelitian ini adalah percakapan yang didalamnya terdapat kalimat tuturantuturan yang mencerminkan prinsip kerja sama dalam bahasa transaksi jual beli online di Tokopedia.com beserta konteksnya.Penelitian ini menggunakan sumber data tertulis, yaitu toko online yang ada di media sosial yaitu Tokopedia. comyang diambil pada bulan Januari 2016 hingga Maret 2016. Tokopedia. com dipilih sebagai sumber data karena dalam Tokopedia.com tersebut tersedia percakapan yang didalamnya terdapat kalimat yang mengandung prinsip kerja sama.

Metode yang digunakan untuk menyediakan data dalam penelitian ini adalah metode simak. Penelitimenyimak penggunakan bahasa yang mengandung prinsip kerja sama yang terdapat pada toko online Tokopedia.com. Teknik yang digunakan untuk menyediakan data dalam penelitian ini adalah teknik catat. Penulis mencatat data berupa kalimat yang mengandung prinsip kerja sama dalam bahasa transaksi jual beli online di Tokopedia.com.

Teknik klasifikasi data dapat dilakukan dengan cara menggunakan kartu data. Penggunaan kartu data berfungsi untuk mendeskripsikan data 
dalam bentuk teks tuturan sekaligus menjelaskan konteks situasi tuturan. Analisis data dalam penelitian ini dilakukan dengan menggunakan teknik analisis cara-tujuan (means-end). Leech menerangkan bahwa analisis caratujuan umumnya diterapkan pada penggunaan bahasa secara komunikatif (1993:55-61).

Selain menggunakan teknik analisis cara-tujuan, analisis data dalam penelitian ini dilakukan dengan menggunakan analisis heuristik dan kontekstual. Leech (1993:55-61) menerangkan bahwa analisis heuristik adalah jenis analisis pemecah masalah yang dihadapi penutur dalam menginterpretasikan sebuah tuturan. Analisis data dengan menggunakan metode analisis heuristik di dalam penelitian ini dilakukan penulis dengan cara menunjukkan konteks tuturan. Kontekstual adalah cara analisis yang diterapkan pada data dengan mendasarkan, memperhitungkan dan mengaitkan identitas konteks-konteks yang ada (Kunjana Rahardi, 2005:16).

Teknik klasifikasi data dapat dilakukan dengan cara menggunakan kartu data. Penggunaan kartu data berfungsi untuk mendeskripsikan data dalam bentuk teks tuturan sekaligus menjelaskan konteks situasi tuturan. Analisis data dalam penelitian ini dilakukan dengan menggunakan teknik analisis cara-tujuan (means-end). Selain menggunakan teknik analisis caratujuan, analisis data dalam penelitian ini dilakukan dengan menggunakan analisis heuristik dan kontekstual. Analisis data dengan menggunakan metode analisis heuristik di dalam penelitian ini dilakukan penulis dengan cara menunjukkan konteks tuturan. Kontekstual adalah cara analisis yang diterapkan pada data dengan mendasarkan, memperhitungkan dan mengaitkan identitas konteks-konteks yang ada.

\section{HASIL DAN PEMBAHASAN}

Pematuhan dan Pelanggaran Prinsip Kerja Sama dalam Bahasa Transaksi Jual Beli Online di Tokopedia.com Pematuhan Maksim Kuantitas

Maksim kuantitas menghendaki seseorang penutur dapat memberikan informasi yang cukup dan memadai. Informasi tersebut tidak boleh melebihi informasi yang sebenarnya dibutuhkan oleh lawan tutur

\section{Konteks Tuturan:}

Penjual menawarkan Gymbal/ Fitnes Ball/ Yoga Ball/ Bola Senam Kettler Original Rp 199.500. Pembeli menanyakan spesifikasi lubang anginnya ada atau tidak.

\section{Bentuk Tuturan:}

$$
\begin{aligned}
& \text { Pembeli :"penutup lubang } \\
& \text { anginnya jual tidak?' }
\end{aligned}
$$

Penjual : "ndak jual mas"

Tuturan yang diucapkan oleh pembeli yakni "penutup lubang anginnya jual tidak?", dan respon penjual terhadap pembeli seperlunya saja yaitu "ndak jual mas". Pematuhan prinsip kerja sama pada maksim kuantitas ini menyebabkan percakapan antara keduanya lebih efektif dan jelas sehingga mudah dipahami. 


\section{Pelanggaran Maksim Kuantitas}

Seorang penutur harus selalu berusaha agar topik pembicaraannya relevan dengan konteks, jelas, mudah dipahami, padat, dan ringkas serta berfokus pada persoalan sehingga tidak menghabiskan waktu begitu saja

\section{Konteks Tuturan:}

Pada konteks percakapan di bawah ini, pembeli menanyakan kepada penjual tentang kapasitas memory yang terdapat dalam Xiaomi Yi Action Camera Travel Edition.

\section{Bentuk Tuturan:}

Pembeli :"yg 8 gb ada ga gan”

\section{Penjual :"ada gan, tapi harga'y tambah 10rb"}

Penjelasan tuturan yang diucapkan penjual tersebut melanggar maksim kuantitas karena termasuk tuturan yang berlebihan. Pembeli tidak menanyakan harga bertambah menjadi 10rb. Sebetulnya, jawaban yang diharapkan oleh pembeli hanya ada atau tidak.

\section{Pematuhan Maksim Kualitas}

Maksim kualitas adalah suatu maksim yang menghendaki setiap penutur mengatakan hal yang sebenarnya (fakta), dengan didasari bukti-bukti yang kuat

\section{Konteks Tuturan:}

Penjual menawarkan barang dagangan kepada pembeli yaitu Grinder Coffe - Penggiling Kopi Rp 900.000. Namun, pembeli menanyakan bisa cod atau tidak karena pembeli mau melihat barangnya langsung.

\section{Bentuk Tuturan:}
Pembeli:"boleh COD gak? Liat barangnya langsung juga.."

\section{Penjual:"bisa bu datang ke showroom kita (Duta Mas, Jakarta Barat).. ibu dari daerah mana?"}

Pembeli:"saya di tomang, jakbar juga,, ada contact person gak?? Biar tau alamat lengkapnya"

Pembeli menanyakan bisa COD atau tidak dengan alasan ingin melihat barangnya secara langsung dan penjual menjawab dengan memberi tahu alamat di daerah Jakarta Barat. Begitu juga informasi yang disampaikan pembeli kepada penjual bahwa rumah pembeli juga daerah Jakarta Barat. Keduanya mematuhi maksim kualitas karena antara penjual dan pembeli menginformasikan alamat dengan sebenarnya.

\section{Pelanggaran Maksim Kualitas}

Jangan mengucapkan suatu kalimat jika kalimat tersebut diyakini salah atau kalimat tersebut tidak tahu persis maksudnya. Inilah yang sering dipergunakan dalam berkomunikasi sehingga terjadi pelanggaran maksim kualitas.

\section{(4) Konteks Tuturan:}

Penjual menawarkan barang berupa Tripod + Holder U Bisa Untuk Hp, Camdig, Handycam Dan Dslr Pendek Rp 90.000. Pembeli menanyakan kepada penjual mengapa barang yang dipesan belum juga sampai karena si pembeli sudah melakukan proses transaksi. 
Bentuk Tuturan:

Pembeli : "makasih ga"

Pembeli : "kok belum sampai ya"

Penjual :"besok mungkin gan, bisa di cek ke jne sekitar anda"

Seperti terlihat pada tuturan data (4), penjual memberikan jawaban yang tidak pasti, adanya tuturan "besok mungkin gan" menimbulkan adanya keraguan atau tidak pasti. Seharusya penjual menjawab dengan pasti barang akan sampai kapan. Jadi, pelanggaran terhadap maksim kualitas ini menyebabkan pembeli terkadang beralih ke penjual lainnya.

\section{Pematuhan Maksim Relevansi}

Maksim relevansi menghendaki penutur berucap secara relevan. Maksim relevansi dijabarkan ke dalam 1 submaksim "Be relevant". Di dalam maksim relevansi, dinyatakan bahwa agar terjalin kerja sama yang baik antara penutur dan mitra tutur, masingmasing hendaknya dapat memberikan kontribusi yang relevan tentang sesuatu yang sedang di tuturkan.

\section{Konteks Tuturan:}

Penjual menawarkan Skmei Unlock 0814 Original Jam Tangan. Pada saat tawar menawar pembeli sudah order pada saat itu juga dan meminta kepada penjual agar segera memproses pemesanan agar barang segera dikirim.

\section{Bentuk Tuturan:}

Pembeli :"uda saya order hari ini langsung dikirim ya"

\section{Penjual :"siap gan, lgsg sy proses pesanannya gan.. J"}

Tuturan penjual dengan pembeli pada data (5) dianggap telah mematuhi prinsip kerja samapada maksim relevansi karena adanya hubungan yang koorperatif antara keduanya. Ketika pembeli mengatakan bahwa si pembeli sudah order dalam hal ini pembeli sudah melakukan transaksi jual beli (transfer uang), kemudian dengan begitu menurut sistem dan aturan penjual segera memproses pemesanannya.

\section{Pelanggaran Maksim Relevansi}

Di dalam maksim relevansi, mengharuskan setiap peserta percakapan memberikan kontribusi yang relevan dengan masalah yang sedang dibicarakan dan informasi yang disampaikan antara penutur dan lawan tutur memberikan hubungan dan masing-masing hendaknya dapat memberikan kontribusi yang relevan.

\section{Konteks Tuturan:}

Penjual menawarkan barang dagangan berupa Hongkong Egg Waffle cetakan kue $\mathrm{Rp}$ 199.000. Pembeli menanyakan dimana lokasi barang itu dijual karena pembeli ingin melihatlihat barang yang lain

\section{Bentuk Tuturan:}

$$
\begin{aligned}
& \text { Pembeli :"semarangnya mn ?? klo } \\
& \text { blh tau mana alamatnya } \\
& \text { skalian mau cri brang lg.." } \\
& \text { Penjual : Kudus sis alamatnya } \\
& \text { ready" }
\end{aligned}
$$


Pembeli menanyakan dimana posisi lokasi Semarang barang itu dijual karena pembeli ingin melihatlihat barang yang lain. Pada data (6), menunjukkan adanya perbedaan pemahaman antara penutur dan mitra tuturnya. Tuturan pembeli "semarangnya mn ?? klo blh tau mana alamatnya skalian mau cri brang lg..,'tidak berhubungan dengan jawaban tuturan dari penjual Kudus sis alamatnya ready.

Di sini, pembeli tidak mengetahui bahwa lokasi tokonya berada di Kudus. Namun si pembeli, menanyakan bahwa toko tersebut di Semarang, padahal aslinya di Kudus. Jadi, pelanggaran terhadap maksim relevansi yang terjadi dalam data (6) tidak ada latar belakang pengetahuan yang sama antara penjual dan pembeli

\section{Pematuhan Maksim Cara}

Maksim cara membuatseseorang penutur menghindari ungkapan yang tidak jelas (kabur) menghindari ketaksaan atau ambigu.

konteks Tuturan:

Penjual menawarkan Brica B-Pro 5 Alpha Edition Rp 1.340.000. Pembeli menanyakan warnaapasajakamerayang ready dan dan perbandingan kualitas dengan kamera xiaomy yi (kamera yang hampir sama spesifikasinya).

Bentuk Tuturan:

Pembeli : “gan ready warna apa?

Bagus mana sama
xiaomi $y i$ ?"

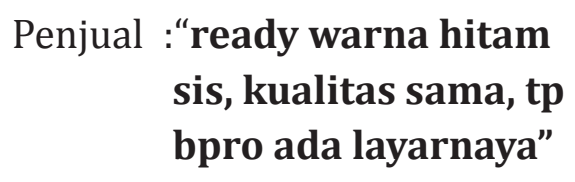

Tuturan penjual yakni, "kualitas sama, tp bpro ada layarnaya". Jika dilihat percakapan yang terjadi antara penjual dengan membeli pada tuturan tersebut terlihat bagaimana cara penjual untuk mengalihkan pembicaraan dari pertanyaan yang dilontarkan oleh pembeli. Ketika pembeli bertanya tentang perbandingan kualitas kamera tersebut, pembeli mengalihkan dengan mengatakan bahwa barang tersebut keduanya mempunyai kualitas sama. Hal ini yang dimaksutkan sama seperti yang bagaimana tidak diterangkan oleh penjual sehingga terasa kabur.

\section{Pelanggaran Maksim Cara}

Maksim cara membuat seseorang penutur menghindari ungkapan yang tidak jelas (kabur) menghindari ketaksaan atau ambigu. Apabila orang bertutur tidak menimbangkan hal-hal tersebut maka dapat dikatakan bahwa orang tersebut melanggar prinsip kerja sama pada maksim cara.

\section{Konteks Tuturan:}

Penjual menawarkan Sepatu Kerja Pantofel Formal Pria Big Size Ukuran Besar 44,45 dan 46 Rp 333.000. Pembeli menanyakan ukuran 45 ada atau tidak karena pembeli butuh cepat karena digunakan untuk keperluan.

\section{Bentuk Tuturan:}

Pembeli :"ukuran 45 nya ada?"

$$
\begin{aligned}
\text { Pembeli :"sy perlunya di pakai } \\
\text { tanggal } 16 \text { makannya } \\
\text { butuh proses cepat bs } \\
\text { gak?" }
\end{aligned}
$$
Penjual :“ada gan, silahkan langsung diangkut saja biar bisa ikut kirim hari ini"


Tuturan pembeli yakni, "sy perlunya di pakai tanggal 16 makannya butuh proses cepat bs gak?", kemudian respon dari penjual yakni, "ada gan, silahkan langsung diangkut saja biar bisa ikut kirim hari ini". Percakapan yang terjadi antara penjual dengan pembeli tersebut memperlihatkan adanya makna ambigu dalam ujaran yang dituturkan oleh penutur. Dikatakan ambigu karena konteks pada percakapan tersebut hal yang diangkut yang dimaksutkan dalam data tersebut adalah sepatu dengan ukuran 45 yang ditanyakan oleh pembeli.

Alasan Terjadinya Pematuhan dan Pelanggaran Pinsip Kerja Sama dalam Bahasa Transaksi Jual Beli Online di Tokopedia.com.

Adanya pematuhan prinsip kerja sama dalam penelitian ini disebabkan:

a. Maksim Kuantitas (The Maxim of Quantity)

Pematuhan prinsip kerja sama pada maksim kuantitas ini menyebabkan tuturan percakapan antara penjual dengan pembeli lebih efektif, percakapannya juga lebih jelas dan dapat dipahami oleh lawan tutur.

b. Maksim Kualitas (The Maxim of Quality)

Pematuhan prinsip kerja sama pada maksim kualitas digunakan oleh penjual dan pembeli. Hal ini dapat memberi alasan terhadap kondisi penjual dan pembeli. Kondisi yang dimaksudkan dalam hal ini yaitu kondisi yang melingkupi banyak hal, misalnya kondisi barang dagangan yang dijualnya. c. Maksim Relevansi (The Maxim of Relevance)

Pematuhan prinsip kerja sama pada maksim relevansi ini diharapkan dapat menarik pembeli sehingga barang dagangannya bisa laku terjual.

d. Maksim Cara (The Maxim of Manner) Pematuhan prinsip kerja sama pada maksim cara ini diharapkan percakapan antara keduanya dapat menghindari ambiguitas. Hal tersebut dilakukan agar komunikasi antara keduanya berjalan dengan lancar dan tepat.

Adanya pelanggaran prinsip kerja sama dalam penelitian ini disebabkan:

e. Maksim Kuantitas (The Maxim of Quantity)

Pelanggaran prinsip kerja sama pada maksim kuantitas dilakukan oleh penjual. Tujuannya yaitu penjual meyakinkan pembeli agar tidak ragu dengan kualitas barang yang akan dibelinya.

f. Maksim Kualitas (The Maxim of Quality)

Pelanggaran prinsip kerja sama pada maksim kualitas dilakukan oleh penjual karena penjual tidak yakin dengan barang yang dijualnya. Hal tersebut mengakibatkan terkadang pembeli beralih ke penjual barang lainnya. Selain itu, pelanggaran maksim kualitas menyebabkan pembeli kecewa dan berdampak kepada pembeli yang akan berpengaruh atau tidaknya terhadap pelanggaran tersebut. 
g. Maksim Relevansi (The Maxim of Relevance)

Pelanggaran prinsip kerja sama pada maksim relevansi menyebabkan pembeli menjadi kebingungan. Selain itu, dalam interaksi yang sedang berlangsung menyebabkan komunikasi kurang lancar.

h. Maksim Cara (The Maxim of Manner) Pelanggaran prinsip kerja sama pada maksim cara terkadang menimbulkan penafsiran lain. Jika keduanya tidak mempunyai latar belakang pengetahuan yang sama, pembeli menanggapinya dengan cara kurang tepat.

\section{Bahasa Transaksi pada Jual Beli Online}

Dalam peristiwa tuturnya penjual dan pembeli dalam berinteraksi dominan menggunakan bahasa Indonesia meskipun ada bahasa lainnya. Hal itu karena keduanya memiliki latar belakang yang sama sehingga dalam berinteraksi menggunakan bahasa Indonesia.

Tingkat tutur dalam bahasa transaksi jual beli di Tokopedia.com yaitu pembeli memberi peluang pertukaran kata, di sini dapat diartikan bahwa yang mengawali interaksinya terlebih dahulu adalah pembeli. Penjual dan pembeli melakukan tawar menawar agar dapat meminimalisasi barang yang dijual dan barang yang akan dibeli. Penjual memperoleh keuntungan (laba) begitu pula pembeli ingin memperoleh harga yang murah.

Interaksi antara penjual dengan pembeli memiliki hubungan sosial yang bersifat positif, mengarah ke suatu kerja sama yang tujuannya untuk melakukan pendekatan-pendekatan seperti, menawarkan jenis barang, memberi kebebasan untuk memilih barang, dan menanyakan barang yang akan dibelinya sudah mencakup atau belum.

Pada penelitian ini, wujud bahasa transaksi pada jual beli online terdapat bentuk panggilan yang berbeda-beda. Adapun bahasa transaksi jual beli pada penelitian ini adalah:

a. Sis (Sista)- digunakan untuk pembeli perempuan.

Sista dapat diartikan bahwa penjual dalam melayani pembeli menggunakan panggilan sis. Hal ini dikarenakan faktor umur antara penjual dengan pembeli sebaya. Panggilan sis juga menunjukkan keakraban dan tidak merasa segan ataupun canggung.

b. Bro (Brother) - digunakan untuk pembeli laki-laki.

Brother dapat diartikan bahwa penjual dalam melayani pembeli menggunakan panggilan bro. Hal ini dikarenakan faktor umur antara penjual dengan pembeli sebaya. Panggilan bro juga menunjukkan dalam bertutur keduanya menunjukkan keakraban dan tidak merasa segan ataupun canggung

c. Gan (Agan/Juragan) - digunakan untuk pembeli laki-laki dan perempuan.

Agan dapat diartikan bahwa penjual dalam melayani pembeli menggunakan panggilan gan. Hal tersebut dikarenakan karena faktor umur antara penjual dengan pembeli yang sebaya. Penggilan gan menunjukkan keakraban atau 
intimate sehingga tidak terasa segan atau canggung.

d. Bos - digunakan untuk pembeli laki-laki.

Bos dapat diartikan bahwa penjual dalam melayani pembeli menggunakan panggilan bos. Hal tersebut dikarenakan penjual ingin menunjukkan kesopanan kepada pembeli dan umur penjual lebih muda dari pada pembeli. Panggilan bos bertujuan agar pembeli merasa dihormati sehingga mau membeli barang yang ditawarkan atau untuk menarik simpati dari pembeli.

e. Mas - digunakan untuk pembeli laki-laki.

Mas sini dapat diartikan bahwa penjual dalam melayani pembeli menggunakan panggilan mas. Hal tersebut dikarenakan tingkat umur penjual lebih muda dari pada pembeli. Penjual menggunakan panggilan mas kepada pembeli, hal itu terlihat lebih ngajeni dan sopan dalam melayani.

f. Mbak - digunakan untuk pembeli perempuan.

Mbak dapat diartikan bahwa penjual dalam melayani pembeli menggunakan panggilan mbak. Hal tersebut dikarenakan tingkat umur penjual lebih muda dari pada pembeli. Penjual menggunakan panggilan mbak kepada pembeli, hal itu terlihat lebih ngajeni dan sopan dalam melayani.

g. Pak (Bapak) - digunakan untuk pembeli laki-laki.

Bapak sini dapat diartikan bahwa penjual dalam melayani pembeli menggunakan panggilan pak. Hal tersebut bertujuan agar pembeli merasa lebih dihomati sehingga menarik untuk membeli barang yang ditawarkannya. Pembeli menghormati penjual disebabkan karena umur penjual lebih muda dari pada pembeli sehingga menunjukkan sikap kesopanan.

h. Buk (Ibuk) - digunakan unutk pembeli perempuan.

Ibuk dapat diartikan bahwa penjual dalam melayani pembeli menggunakan panggilan buk. Hal tersebut bertujuan agar pembeli merasa lebih dihomati sehingga menarik untuk membeli barang yang ditawarkannya. Pembeli menghormati penjual disebabkan karena umur penjual lebih muda dari pada pembeli sehingga menunjukkan sikap kesopanan.

i. Kak (Kakak) - digunakan untuk pembeli perempuan.

Kakak dapat diartikan bahawa penjual dalam melayani pembeli menggunakan panggilan kak. Hal tersebut menunjukkan adanya keakraban yang terjadi antara keduanya sehingga keduanya tidak merasa segan atau canggung.

\section{SIMPULAN}

Berdasarkan penelitian prinsip kerja sama dalam bahasa transaksi jual beli online di Tokopedia.com, bentuk penerapan prinsip kerja sama yang terdapat dalam bahasa transaksi jual beli online di Tokopedia.com ditemukan empat jenis pematuhan dan pelanggaran prinsip kerja sama dengan alasan dan motif tertentu pada 
masing-masing maksim, yaitu maksim kuantitas, maksim kualitas, maksim relevansi dan maksim cara. Ditemukan berbagai macam panggilan sapaan yang digunakan. Bentuk bahasa transaksi tersebut yaitu: Sist, Bro, Gan, Bos, Mas, Mbak, Pak, Buk, Kak.

\section{DAFTAR PUSTAKA}

Grice, H.P. (1975). Logic and Conversation. Dalam Peter Cole dan Jerry L. Morgan. (EDS). Syntax and Semantics Volume 3: Speech Acts. New York: Academic Press.

. (2006). Logic and Coversation dalam The Discource Reader (ed Adam Jaworski and Nikolas Coupland). London and New York: Routledge.

Rahardi, K.(2005). Pragmatik: Kesantunan Imperatif Bahasa Indonesia. Jakarta: Erlangga.

Leech, G. (1993). Prinsip-prinsip Pragmatik (Diterjemahkan oleh M.D.D.Oka). Jakarta: Balai Pustaka.

Sudaryanto. (1993). Metode dan Aneka Teknik Analisis Bahasa (Pengantar Penelitian Wahana Kebudayaan Secara Linguistik) Yogyakarta: Duta Wacana University Press.

Suharsono. (2003). Register Tawar Menawar pada Warung Penjaja Buah-buahan Yogyakarta: Pertemuan Ilmiah Bahasa dan Sastra Indonesia (PIBSI) XXV. 